\title{
Renal Capsule
}

National Cancer Institute

\section{Source}

National Cancer Institute. Renal Capsule. NCI Thesaurus. Code C12885.

A layer of dense connective tissue that covers the outer surface of each kidney. 